\title{
DETERMINANTS OF COMMERCIAL BANKS' PROFITABILITY. EVIDENCE FROM HUNGARY
}

\begin{abstract}
Isah Serwadda ${ }^{1}$
${ }^{1}$ Department of Finance, Faculty of Business and Economics, Mendel University, Zemědělská 1, 61300 Brno, Czech Republic

To cite this article: SERWADDA ISAH. 2018. Determinants of Commercial Banks' Profitability. Evidence from Hungary. Acta Universitatis Agriculturae et Silviculturae Mendelianae Brunensis, 66(5): 1325-1335.
\end{abstract}

To link to this article: https://doi.org/10.11118/actaun201866051325

\begin{abstract}
This paper aims to find out whether bank-specific (internal) factors impact on the profitability of commercial banks in Hungary for 16 a year period ranging from 2000-2015. The study employs a sample of twenty-six commercial banks with four hundred sixteen observations. The study employs return on average assets (ROAA) as a proxy for bank profitability, and it also considers bank-specific (internal) factors as independent variables. These include asset quality (non-performing loans), overhead costs, bank size, net interest margin, and liquidity risk plus capital adequacy ratio. The study uses panel regressions, descriptive statistics and correlation analysis for the investigations. The panel regression models are to estimate the impact of bank-specific (internal) factors on bank profitability. The Hausman specification test was conducted on the panel regression models in order to identify the best and appropriate model for the study. The empirical findings reveal that non-performing loans, overhead costs and liquidity had a significant negative impact on bank profitability as bank size had a significant positive impact on profitability. However, net interest margin and capital adequacy ratio had no impact on bank profitability. The study concludes that bank size and asset quality are bank-specific factors that have the biggest impact on commercial banks' profitability in Hungary for the period under investigation.

The study recommends that commercial banks should endeavor to manage and reduce overhead costs to be able to earn more profits since overhead costs adversely affect bank profitability. More so, commercial banks' managers should regularly monitor credit and liquidity risk indicators as well as pursuing diversification policies of income sources while upholding optimisation of operational costs.
\end{abstract}

Keywords: bank, profitability, liquidity, credit risk, Hungary

\section{INTRODUCTION}

Commercial banks pursue a vital role in economic resource allocation of any sound economy globally especially when they carry out an intermediary role by channeling finances from depositors to investors regularly (Ongole and Kusa, 2013). More so the banking field has the potential of coordinating the funds of an economy by transferring the finances from the savings envelopes to investment projects (Nshimiyimana and Zubeda, 2017).

The banking sector is a vital sector in that it promotes economic growth (Lipunga, 2014). In an attempt to support economic activities commercial banks offer deposits and credit facilities for personal and corporate customers and also provide access to the nations' payment systems 
(Handley-Schachler, et al., 2007). Meanwhile, banks are also vehicles of transmitting effective monetary policy of the central banks, hence assisting central banks to stabilise their economies (Siddiqui and Shoaib, 2011).

The soundness of the banking industry is a crucial issue for the excellent and healthy status of an economy (Sufian and Chong, 2008). On the contrary, the underperformance of banks may culminate in the financial crisis with its negative repercussions on the economic growth and development of a country. Hence, the banking crisis may consequently result in economic meltdown like what transpired in the United States in 2007(Marshall, 2009).

Given, the deteriorating health status of the banking institutions in some economic circles coupled with the previous global financial crisis, it is worth examining the financial performance of banks, mostly by academicians and the industry specialists. Important to note is that the vibrancy of any bank dramatically depends on its financial performance which usually reflects the strength and weaknesses of particular banks (Makkar and Singh, 2013). This financial performance is determined by the profitability of banks. Hence, profits motivate shareholders for more business opportunity investments (Ongole and Kusa, 2013). Ayanda (et al., 2013) stresses profitability is defined as the bank's capacity to generate profits year after year. Podder (2012) states profitability is the efficiency of a bank to raise revenue or earnings.

Generally, the financial performance of banks is determined by the internal and external factors. Internal determinants rise from the financial statements of commercial banks like balance sheet and income statements; hence these can be termed as bank-specific factors of profitability (Wahdan and Leithy, 2017). External factors are ones that are not related to banks' management, but they constitute the economic and regulatory environment in which banks operate and usually impact on banks indirectly as well (Tobias and Themba, 2011).

The paper aims at examining whether the determinants of banks specific factors impact on the profitability of Hungarian commercial banks for a sixteen year period ranging from 2000-2015 and also contribute to the literature gap of Hungary as an emerging economy in particular.

This is because several studies on the profitability of commercial banks have been conducted elsewhere other than Hungary in particular as the commonest empirical research at hand is mostly on CEE (Central and Eastern Europe) in general. Meanwhile, the Hungarian banking sector is composed of both domestic and foreign banks. As a country, it has gone through a lot of transitions. Banking in Hungary began way back in 1948 as a result of the Soviet Union's system where the National bank of Hungary assumed the monopoly of money circulation plus the entire credit system in the economy.

Meanwhile, Hungary has been perceived as one of the best performing emerging economies having successfully achieved macroeconomic stabilisation and its creation of a market-driven economic system (Fischer and Sahay, 2000, Weder, 2001). Following the political and economic changes of 1989 in central and Eastern Europe (CEE), the newly and democratically elected governments set up new banking and financial systems. During this transition, there was a new wave of banking where market-oriented systems were established after the collapse of centralised state-owned banking systems giving room for the emergence of privately owned banks in the market. Banking activities were greatly regulated reducing competition amongst banks, thus creating market segmentation. However, the industrial banking sector's image greatly changed after1989 when traditional commercial banks which highly concentrated on corporate customers, later on, opened up for retail banking in Hungary. This enabled such retail financial institutions to access commercial banking licenses. Additionally, in the previous years, partly as a result of financial crisis, there was somewhat a need for balance sheet adjustments, fiscal and monetary regulations changed dramatically and sometimes compliance with these changes required massive resource allocation leading to enormous investments for Hungary.

On the contrary, not only macro matters but also micro for an economy's success. Rigorous competition in the banking industry reduces the margins and fees type of incomes. Hence banks need to be cautious of the risks upon their books if they are to enhance their profitability levels as this is entirely necessary for healthy functioning of the banking industry.

Thus, it's against this preamble that the paper is set to examine bank-specific (internal) factors on the Hungarian commercial banks in an emerging economy for the period ranging from 2000-2015. It's important to note that a lot has been researched upon bank profitability elsewhere in other emerging economies, however with little attention to the Hungarian economy. Hence the current study is set to bridge this gap by examining the bank-specific factors on commercial banks' profitability of Hungary for the period 2000-2015.

The study employs return on average assets (ROAA) as a performance proxy, and it also considers bank-specific determinants as independent variables. These include asset quality (non-performing loans), overhead costs, bank size, net interest margin, and liquidity risk plus capital adequacy ratio.

This paper is organised in a way that the first section covers the introduction, the second covers literature review, the third section covers research 
methodology, the model used and the variables description employed in the regressions, the fourth handles the discussion and interpretation of results and the final section draws the conclusion with possible recommendations.

\section{Related literature review}

Previous studies on bank profitability have been conducted by employing both bank-specific factors and macroeconomic factors across the globe, however bank-specific have significantly influenced on profitability of banks namely; Bhatia,Mahajan and Chander(2012); Sufian and Noor(2012) in India; Liu and Wilson(2010) in Japan,Shoaib,Wang,Jaleel and Peng(2015) in Pakistan.

Menicucci and Paolucci (2016) examined the relationship between bank-specific factors and profitability in the European banking industry to establish the effect of internal factors on scoring high profitability. The study used regression analysis performed on the unbalanced dataset for 28 banks for the period ranging from 2006-2015. Authors identified the biggest bank for every single country of the European Union. Regression findings portrayed that capital adequacy ratio and bank size has a positive effect on bank profitability whereas higher asset quality resulted into reduced profitability levels. Results of this study recommend that banks with higher deposit ratio tend to be more profitable. The single bank's characteristic illustrates a fraction of within-country differences in European bank profitability proposing that more close attention is paid to bank-specific factors to enhance bank profitability. More so, the study findings may be very purposeful to would be investors when making decisions and may as well be resourceful to global institutional investors seeking for lucrative business opportunities in Europe.

Mauricio Jara-Bertin, Jose Arias Moya, Arturo Rodriguez Perales(2014) realised a positive relationship between capital adequacy and profitability when they employed a panel data of 78 commercial banks from Argentina, Brazil, Chile, Colombia, Mexico, Paraguay, Peru and Venezuela for the period 1995-2010.

Shoaib, Wang, Jaleel and Peng(2015) performed a study employing POLS regressions model using panel data of Pakistan banks for the period for 2006-2013. From their empirical findings, they observed that liquidity, administrative expenses and non-performing loans negatively impacted profitability whereas capital adequacy influenced positively on profitability.

According to Olalekan and Adeyinka (2013) from their research work, analysed the effect of capital adequacy on the profitability of deposit-taking institutions in Nigeria. The study examined the impact of capital adequacy on the profitability of both local and foreign banks in Nigeria. The study employed primary data collected through questionnaires that were distributed to different employees of these banks, and it engaged a sample of 518 participants with a response rate of $76 \%$.In a related development, the authors also employed secondary data collected from financial statements for the period 2006-2010. Results from primary data realised an insignificant relationship between capital adequacy and bank profitability; however secondary data employed reported a positive and significant relationship between capital adequacy and profitability. Hence this meant that capital adequacy is very instrumental in determining profitability for these deposit-taking institutions.

Acaravci, S.K and Calim, A.E (2013), from their findings on private commercial banks, realised that deposit volume had an insignificant effect on profitability, higher non-performing loans adversely impacted on profitability while capital adequacy had a significant and positive impact on bank profitability. Lee and Hsieh (2013); Menicucci and Paolucci (2016) stressed that more significant volumes of deposits result in more significant profits. The same findings were advanced by Saeed (2014) in his empirical study though Dermiguc-Kunt and Huizinga (1999) realised mixed relationships between deposits and profitability.

Kosmidou, Tanna and Pasiouras (2005) conducted an empirical study on UK owned commercial banks for the period 1995-2002 employing bank-specific factors, macroeconomic factors and financial market structure on profitability. Their investigation revealed that capital strength and efficiency in expenses management had a positive and significant impact on performance.

Elsiefy (2013) stressed that banks with substantial investments in liquid assets could manage liquidity distress. It only becomes problematic in identifying the optimum level of liquidity given by the risk versus trade-off. They stressed that more considerable liquidity compared to the average of the industry is an impression of inefficiency. Thus the more substantial the liquidity, the less the profitability, meaning that there is a negative relationship between liquidity and profitability.

According to Abel and Le Roux (2016) examined the determinants of the banking profitability industry in Zimbabwe for the period 2009-2014. The overall findings stressed that bank-specific factors greatly influence the profitability of the banking industry. The study results revealed that the profitability of the banking industry is dependent on bank-level management variables. Hence this finding is very purposeful for optimal policies for bank management on how they can improve on profitability levels. More so, the authors identified that profitability is related to banks that hold relatively more massive amounts of capital, liquid assets, and lower levels of asset quality (non-performing loans) coupled with efficient expense management. Therefore the authors recommended that the profitability of Zimbabwean banks can be enhanced by improving the quality of assets, improving expense management and liquidity. 


\section{Profitability features and determinants}

Financial performance is determined by considering the relationship between the balance sheet and the profit and loss account (Makkar and Singh2013). The practice of managing the relevant relationship is termed as financial analysis which is composed of financial ratios calculations. Many ratios can be ascertained in examining profitability, Ongole and Kusa (2013) stress that return on assets (ROA) is observed as one of the different profitability measures.

ROA determines the capacity of bank management in generating income by employing company assets at hand (Ongole and Kusa, 2013). This implies that the ratio portrays how much net income is produced on each unit of assets, thus the higher the ROA, the higher the bank profitability and vice versa (Kumbirai and Webb, 2010).

Return on equity (ROE) is also one of the many measures that determine how much profits are realised for the company concerning the total amount of shareholders' equity as indicated on a balance sheet. ROE is termed as the percentage rate of return on each unit of equity invested by bank's shareholders (Kumbirai and Webb, 2010). Hence the higher, the return on equity, the better for the bank as it will be in a position to raise more funds internally (Ongole and Kusa, 2013). Prevailing literature is in favour of ROA to ROE, and the argument advanced for this is that ROE does not provide room for the banks' financing through borrowings of which ROA does (Kalluci, 2011). Hence ROE offers fewer insights into bank profitability (Alkhatib and Harsheh, 2012).

However, the current study intends to employ ROAA as the proxy for banks' profitability in Hungary. ROAA is applied because it considers average yearly values of assets and this reflects performance more precisely and accurately compared to end year values. According to Alkhatib and Harsheh (2012) observed and suggested some determinants that can enhance banks' performance and these were bank size, operational efficiency level, leverage ratio, portfolio composition. The study employs return on average assets (ROAA) as a proxy for bank profitability, and it also examines six factors to determine their impact on profitability namely; asset quality(non-performing loans), overhead costs, bank size, net interest margin, liquidity risk and capital adequacy ratio.

\section{MATERIALS AND METHODS}

This study employed an analytical approach by using a strongly balanced panel data for twenty-six Hungarian commercial banks for the period 2000-2015 operating in the Hungarian banking sector to achieve the intended objectives. The paper aims to examine and find out whether bank-specific (internal) factors impact on the profitability of commercial banks in Hungary for 16 a year period ranging from 2000-2015. The study uses annual data from the Bank scope database together with published annual income financial statements as well balance sheets of commercial banks in Hungary for a sixteen year period ranging from 2000-2015 resulting into a total of four hundred sixteen year bank observations to approximate the relevant ratios and coefficients. The financial statements were collected from the banks' websites. As observed and quoted from Tobias and Themba(2011) the merit of employing panel data is that it controls for individual heterogeneity, less collinearity amongst variables and also controls trends in data, an issue time series data may not comfortably handle.

Data were analysed by employing descriptive statistics to estimate the mean and standard deviation of variables.

The study also employs fixed and random effects models for estimation purposes while using the Hausman specification test to select the appropriate model for analysis. Correlational analysis and variation inflation factor are employed to check for multicollinerity issues.

The study also adopts the Augmented Dickey-Fuller test to determine the stationarity of the variables employed through the use of a panel unit root test (Levin-lin-Chu).

Previous empirical studies regarding bank performance employ different approaches ranging from profitability ratios to complex ones. However, the commonest performances proxies are return on assets (ROA) calculated as the ratio of net income to total assets whereas return on equity (ROE) is calculated as the ratio of net income to equity. As the former defines the net relative profit generated by the banks' total assets and is assumed as a measure of management efficiency, the latter determines the net income on the return of capital invested by shareholders of a bank.

Considering, ROE and ROA, the use of ROA takes care of the risks derived from leverage, and it's a paramount bank profitability ratio (Athanasoglou et al., 2005).

Meanwhile, the current study employs return on average assets (ROAA) as the performance metric since it considers average yearly values of assets and this reflects performance more precisely and accurately compared to end year values. In an attempt to manage changes in assets in the fiscal year, the current study relies on average assets value. ROAA determines the ability of a banks' management to realise profits from banks' assets. In this case, ROAA portrays how banks' assets are managed to produce bank revenue.

\section{Model specification}

The study employs one model to determine bank profitability through regression analysis with the help of one performance indicator namely return on average assets (ROAA) defined as the net income divided by the average total assets together with the independent variables which include capital adequacy ratio, liquidity risk, net interest margin, 
bank size, overhead costs, and non-performing loans. Previous studies on bank profitability like those of Athanasoglou et al., 2005 and Goddard, et al. (2004) employed linear regressions to examine the impact of different variables' upon bank profit. These variables were selected and considered following the previous studies upon their effect on the profitability of banks (Athanasoglou et al., 2005 and Goddard, et al. (2004) and also to find out whether they have an economic sense or bearing about the Hungarian situation in particular. Hence their consideration and definitions as well in the economic model below;

Thus to analyse the determinants of bank profitability of Hungarian commercial banks, the study employs the following specification model;

$\operatorname{ROAA}_{i t}=\left(\beta_{0}+\beta_{1} C A D_{i t}+\beta_{2} L_{I Q R_{i t}}+\beta_{3} N I M_{i t}+\right.$ $\left.+\beta_{4} B S_{i t}+\beta_{5} O H_{i t}+\beta_{6} N P L_{i t}+\varepsilon_{i t}\right)$

Where $R O A A_{i t}$ is Return on average assets at time, $\beta_{0}=$ Constant or fixed effects, $C A D_{i t}=$ Capital Adequacy ratio at time, $t, L I Q R_{i t}=$ Liquidity risk at time, $t, N I M_{i t}=$ Net Interest Margin, at time, $t$, $B S_{i t}=$ Bank size at time, $t, \mathrm{OH}_{i t}=$ Overhead costs at time, $t, N P L_{i t}=$ Non-performing loans at time, $t$, $\varepsilon_{i t}=$ Stochastic error term at time, .

The model considers the following equation;

$R O A A=\beta_{0}+\beta_{1} X_{i t}+\varepsilon_{i t}$

Where i denote the cross-sectional dimension and t denotes time-series dimension. Meanwhile, ROAA is the dependent variable which is the return on average assets ratio,

$X_{i t}$ Indicates a composition of independent variables, $\varepsilon_{i t}$ is the stochastic error term for the bank, $i$ at the time, $t$ for an estimation model. Both techniques of panel data are employed, and that is fixed effects and random effects models.

\section{Variable description and definitions}

Return on average assets (ROAA) is defined as the net income divided by the average total assets. Golin (2001) stresses that ROAA is considered as a key ratio for examination of bank performance and is observed as the most common measure of banks' performance in the contemporary literature.

Capital adequacy is regarded as one of the financial structures; it portrays how the banks' assets are funded and the ability of a bank to cover its assets (Hassan and Bashir, 2003). This might be reflected by the solvency ratio or capital adequacy ratio (ratio of equity to assets). Notably, higher solvency may have a positive impact on performance as it lowers the risks of the bank (Athanasoglou et al., 2006). Meanwhile, higher solvency will lower the leverage effect, which might increase financing costs (Akbas, 2012).In other words, higher equity in terms of assets implies that the bank is strongly capitalised. Banks with higher capital ratios are expected to have fewer risk threats compared to banks with fewer capital ratios. More so, a higher capital ratio implies that banks' shareholders are more into business operations.

In this current study, loans to customer deposits are considered as a proxy for liquidity risk. Liquidity and profitability usually have a unique and interesting aspect. This is because when banks hold more cash reserves in their cash vaults, they are more liquid and can easily pay instantly their depositors' claims. However, banks' profitability is compromised as banks hold more cash in their cash vaults. On the contrary, banks realise profitability if they disburse more loans, especially with the long loan tenures, though banks are as well exposed if more of their resources are invested for long terms loan facilities.

Banks with higher liquidity levels are assumed to meet their obligations even during hard times. A good liquidity ratio reduces the risk of failure that may lower the financing costs and hence increases profitability (Alexiou and Sofoklis, 2009). When a bank transforms a bigger percentage of its deposits into credit, a bank is expected to score more profits. Hence, the bigger the deposit ratio or liquidity ratio, the bigger, the expected profitability and the bigger, the liquidity risk exposure for the bank. On the contrary, liquid assets fetch fewer returns which lessen bank profitability.

Net interest margin is defined a measure of the difference between the interest income raised by a bank or other financial institutions and the interest paid out to their lenders like deposits relative to the amount of their earning interest-earning assets. It's less the same as gross margin of non-financial institutions. It's usually reflected as a percentage of what the financial institution earns on credit in a given time frame and other assets minus interest paid on borrowed finances divided by the average amount of assets on which it earned income in that time frame called the average earnings assets. NIM is termed as the net interest income divided by total assets. NIM is based on profits earned on interest activities (Berger, 1995; Barajas, et al., 1999 and Naceur and Goaied, 2001).

\section{Bank size}

There are many indices when determining the size of a bank in the contemporary banking literature, and such include total assets, total loans or even total deposits. In this case, bigger banks measured by either of the mentioned indices above may enable banks to enjoy economies or diseconomies of scale (Kosmidou, et al., 2005; Athanasoglou et al., 2006). In the current study, the natural log of total assets will be considered to determine this variable.

Overhead costs are defined as total overhead costs to total assets. They include different forms of salaries and wages paid to employees. They usually have a negative effect on profitability.

Non-performing loans denote banks' credit risk, as its one of the major credit risk factors that impact on banks' performance since it reflects loss profitability as debtors fail to settle their obligations as per the agreed contractual period of repayment. 
I: Summarizes variables employed in the current study and their expected impact on bank profitability.

\begin{tabular}{lcccc}
\hline Number & Abbreviation & Description & Definition & Expected sign(- or + ) \\
\hline $\mathbf{1}$ & ROAA & Return on average assets & Net income/average total assets & \\
$\mathbf{2}$ & CAD & Capital Adequacy & Total equity/Total Assets & $-/+$ \\
$\mathbf{3}$ & LIQR & Liquidity risk & Loans/Customer deposits & $-/+$ \\
$\mathbf{4}$ & NIM & Net Interest Margin & Net interest margin/Total assets & $-/+$ \\
$\mathbf{5}$ & BS & Bank size & Natural log of total assets & $-/+$ \\
$\mathbf{6}$ & OH & Overhead costs & Total overhead costs/Total assets & - \\
$\mathbf{7}$ & NPL & Non-performing loans & Impaired loans(NPL)/Total gross loans & - \\
\hline
\end{tabular}

Hence this compels banks to keep provisioning for such high NPL that impact adversely on banks' profitability. A negative impact on profitability is expected due to bad quality loans or impaired loans (Mansur, et al., 1993).

\section{RESULTS AND DISCUSSION}

Using STATA, the study conducted a panel unit root test (Levin-lin-Chu) to establish whether the variables employed were stationary. The variables employed were all stationary at levels and thus their integrated order of I (0) stochastic process apart from one variable and that this non-performing loans (NPL), hence its integrated order of I (1) as in Tab. II, where $\Delta$ means first order difference.

In Tab. III, presented are the descriptive statistics results for the dependent and independent variables involved in the model. The descriptive statistics were performed to establish the mean differences amongst the variables included in the model for the Hungarian commercial banks for the period under the study of 2000-2015.

As presented from the Tab. III, the results portray that the average value of bank performance is $0.255 \%$ which implies that during the period 2000-2015, on average the total assets of the sampled commercial banks in Hungary generated 0.255\% returns, competing amongst themselves for profit generation. The standard deviation of $2.57 \%$ demonstrates their profit making capacity as it shows how different these banks are when generating profits. ROAA has a minimum value of $-17.737 \%$ and the maximum value of $14.987 \%$.

Non-performing loans (NPL) among the Hungarian commercial banks is varied from 0 to $0.373 \%$ with the mean and standard deviation of $0.031 \%$ and $0.0739014 \%$ respectively. Thus with an average of

II: Uunit root test table

\begin{tabular}{|c|c|c|c|}
\hline Variable & p-value at level & p-value after first order difference & Decision \\
\hline ROAA & 0.0015 & & $\mathrm{I}(0)$ \\
\hline CAD & 0.0000 & & $\mathrm{I}(0)$ \\
\hline LIQR & 0.0011 & & $\mathrm{I}(0)$ \\
\hline$\triangle N P L$ & 0.5848 & 0.0027 & $\mathrm{I}(1)$ \\
\hline BS & 0.0000 & & $\mathrm{I}(0)$ \\
\hline $\mathrm{OH}$ & 0.0005 & & $\mathrm{I}(0)$ \\
\hline NIM & 0.0000 & & $\mathrm{I}(0)$ \\
\hline
\end{tabular}

Source: Author's calculations from STATA, 2018

III: Descriptive statistics results

\begin{tabular}{lccccc}
\hline \multicolumn{1}{c}{ Variables } & Observations & Mean & Std.dev & Min & Max \\
\hline ROAA & 416 & 0.2547332 & 2.565145 & -17.737 & 14.987 \\
NPL & 416 & 0.0313266 & 0.0739014 & 0 & 0.3726305 \\
OH & 416 & 0.0457427 & 0.1439893 & 0 & 2.247766 \\
BS & 416 & 8.914168 & 7.034784 & 0 & 17.76425 \\
NIM & 416 & 3.567358 & 4.951154 & 0 & 26.139 \\
LIQR & 416 & 0.3903954 & 0.3385542 & 0 & 0.9532463 \\
CAD & 416 & 7.350623 & 8.777278 & 0 & 98.454 \\
\hline
\end{tabular}

Source: Author's calculations from STATA, 2018. 
IV: A correlation matrix results

\begin{tabular}{|c|c|c|c|c|c|c|c|}
\hline & ROAA & NPL & OH & BS & NIM & LIQR & CAD \\
\hline ROAA & 1.0000 & & & & & & \\
\hline NPL & -0.2467 & 1.0000 & & & & & \\
\hline OH & -0.0725 & -0.0121 & 1.0000 & & & & \\
\hline BS & 0.0847 & 0.4093 & 0.1761 & 1.0000 & & & \\
\hline NIM & 0.3276 & 0.0345 & 0.3023 & 0.4782 & 1.0000 & & \\
\hline LIQR & 0.1183 & 0.2828 & 0.1512 & 0.8744 & 0.6734 & 1.0000 & \\
\hline CAD & 0.0870 & 0.0521 & 0.5701 & 0.5578 & 0.5853 & 0.5495 & 1.0000 \\
\hline
\end{tabular}

Source: Author's calculations from STATA, 2018.

V: Results of TV and VIF factors for bank profitability.

\begin{tabular}{llc}
\hline \multicolumn{1}{c}{ Independent variables } & VIF & 1/VIF \\
\hline LIQR & 6.98 & 0.143355 \\
BS & 5.98 & 0.167165 \\
CAD & 2.60 & 0.384152 \\
NIM & 2.52 & 0.396598 \\
OH & 1.58 & 0.631022 \\
NPL & 1.30 & 0.769882 \\
Mean VIF & 3.49 & \\
\hline
\end{tabular}

Source: Author's calculations from STATA, 2018, Note: VIF = Variation Inflation Factor.

$0.031 \%$, it implies that the Hungarian commercial banks have a relatively good asset quality.

The bank cost which is denoted by overhead costs to total assets has an average of $0.046 \%$. This implies that Hungarian commercial banks managed their costs well concerning the total assets for the period under study.

The bank sizes (BS) and net interest margin (NIM) have a mean of $8.914 \%$ and $3.567 \%$ respectively. Bank size and net interest margin also have minimum and maximum values of 0 and 17.76425 and 0 and 26.139 respectively.

Regarding liquidity risk, the study assumes that banks with high liquidity will experience low profitability and vice versa. In this case, the study observes a mean value of 0.3903954 for liquidity with minimum and maximum values of 0 and 0.9532463 respectively and a standard deviation of 0.3385542 .

The capital adequacy ratio mean is 7.350623 with the minimum and maximum values of 0 and 98.454 respectively and a standard deviation of 8.777278

Correlation coefficients represent a linear relationship between variables. The most commonly applied correlation coefficient is the Pearson's correlation also known as linear or product-moment correlation.

The significance level computed for each correlation is a significant source of information about the reliability of correlation.

Thus to examine the relationship between the dependent and independent variables, correlation coefficients were computed and presented through the correlation matrix as in Tab. IV.
From the Tab. IV, the results indicate that there was a significant negative relationship between non-performing loans and return on average assets. This implies that as non-performing loans increase, bank profitability decreases.

The results also indicate that there was a significant negative association between overhead costs and return on average assets. This means that as the operational costs increase, the bank profitability reduces.

The results from the Tab. IV, portray that there was a significant positive relationship between bank size and bank profitability. This means that as bank size increases, bank profitability also increases.

The results from the Tab. IV also show that there was a positive relationship between net interest margin and bank performance.

The results also from the table indicate there was a significant relationship between liquidity and bank profitability. This implies that as liquidity increases, bank performance also increases.

The results also show that there was a positive and insignificant relationship between capital adequacy ratio and bank profitability. This implies that capital adequacy had no impact on bank performance.

For the case of VIF, as in Tab. v, if the results do not exceed 10 and the tolerance level is near, 0 , this implies that there is no problem of multicollinerity (Gujarati, 2003). Results of VIF and tolerance level are presented in the Tab. V.

As observed from Tab. V, none of the independent variables is experiencing VIF ratio greater than 10 and the tolerance level is near 0 , an impression 
VI: Results of regression models of FE and RE

\begin{tabular}{lcc}
\hline \multicolumn{1}{c}{ Variables } & FE Model(ROAA) & RE Model(ROAA) \\
\hline NPL & $-11.85449^{* * *}(-6.61)$ & $-11.69942^{* * *}(-6.70)$ \\
OH & $-2.758705^{* * *}(-3.12)$ & $-2.978251^{* * *}(-3.33)$ \\
BS & $0.1055996^{* *}(2.01)$ & $0.1277568 * * *(2.75)$ \\
NIM & $0.0167614(0.27)$ & $0.1692972^{* * *}(3.50)$ \\
LIQR & $-2.221587^{* *}(-2.14)$ & $-2.968417 * * *(-3.06)$ \\
CAD & $0.0171465(0.81)$ & $-0.0065869(-0.32)$ \\
cons & $0.492418^{* *}(2.21)$ & $0.2219538(0.80)$ \\
\hline
\end{tabular}

Robust standard errors in parentheses $* \mathrm{P}<0.10,{ }^{* *} \mathrm{p}<0.05,{ }^{* * *} \mathrm{p}<0.01$

Source: Calculations of author from STATA, 2018

Number of obs $=416, \mathrm{~F}(6,409)=22.89$, Prob $>\mathrm{F}=0.0000$, R-squared $=0.2514$, Adj R-squared $=0.2404$

that multicollinerity issues are absent. Hence, the independent variables identified for the model are best suited for regression analysis.

R-squared for the regression is 0.2514 which implies that the explanatory variables in the current study can explain 25 per cent of the variations in the financial performance metric, return on average assets. The remaining 75 per cent of variations of the financial performance of commercial banks under investigation can be explained by other factors not included in the model.

\section{Regression analyses between variables and respective discussions}

This section presents the results of the regression analysis between variables and discussions. This paper aimed at examining whether bank-specific determinants impact the profitability of commercial banks in Hungary considerably.

The following findings of fixed effects model and random effects model present the impact of determinant factors on the financial performance of commercial banks in Hungary measured by the performance indicator of Return on average assets (ROAA).

Tab. VI, presents two different but related models of the empirical findings of this study to account for the factors that determine the profitability of Hungarian commercial banks for the sample study. The fixed effects model was first run and the study assumed that unobserved effects are correlated with determinant factors of profitability. Then the random effects model is run where the initial assumption of correlation are reversed on the same covariates. After that, the Hausman specification test was performed to establish which model best suits the sample study under investigation.

Tab. VI presents the parameters of estimation and standard errors realised from the fixed effects model and the random effects model and the between effects model with ROAA as the dependent variable.

Regression analysis with the FE model from the investigations, the study observed that there was a strong negative relationship between non-performing loans and banks' performance. This means that as the non-performing loans increase, bank profitability is decreased. These findings conform to those of Achou and Tegnuh (2008); Felix and Claudine (2008); Kargi (2011); Epure and Lafuente (2012) and Kodithuwakku (2015) who identified a negative association between non-performing loans and bank performance. However, these findings contradict those of Li and Zou (2014) and Alshatti (2015) who realised a positive impact of non-performing loans on bank performance. The overhead costs to total assets are hugely significant and impact negatively on bank performance. This implies that as the operational costs of the bank increases, bank profitability reduces. As per the prior expectations, bank size has a significant positive relationship with bank performance. This means that as the bank size increases, bank profitability also increases. This coefficient of bank performance was expected, and the findings are in harmony with those of Bikker and $\mathrm{Hu}$ (2002) and Goddard, et al. (2004) who found a positive relationship between bank size and bank performance.

Moreover, the findings of the study portray that larger Hungarian banks experience better performance compared to the smaller ones. There was a positive relationship between net interest margin and bank performance though statistically insignificant, implying that net interest margin did not affect banks' profitability. Liquidity findings portray that there is a negative relationship between liquidity and bank profitability. This means that having more liquid assets results in a reduction of profitability. These findings are consistent with the results of Goddard, et al. (2004). The current study findings illustrate that capital adequacy ratio is favorable though statistically insignificant. This implies that the capital adequacy ratio had no impact on banks profitability.

With the RE model, the study observes similar results with FE regarding non-performing loans, overhead costs, bank size and liquidity. However, the only differences are observed with two variables namely net interest margin and capital adequacy ratio, whereby with net interest margin the study realised a significant positive relationship between 
VII: Results of the Hausman specification test

\begin{tabular}{lcccc}
\hline & $(\mathbf{b})$ & $(\mathbf{B})$ & $(\mathbf{b}-\mathbf{B})$ & sqrt(diag(V_b-v_B $)$ ) \\
\hline Variables & $(\mathrm{Fe})$ & $(\mathrm{Re})$ & (Difference) & 0.4150785 \\
NPL & -11.85449 & -11.69942 & -0.1550775 & 0.0324167 \\
OH & -2.758705 & -2.978251 & 0.2195466 & 0.0244015 \\
BS & 0.1055996 & 0.1277568 & -0.0221572 & 0.038836 \\
NIM & 0.0167614 & 0.1692972 & -0.1525358 & 0.3762089 \\
LIQR & -2.221587 & -2.968417 & 0.7468302 & 0.0055376 \\
CAD & 0.0171465 & -0.0065869 & 0.0237334 & \\
\hline
\end{tabular}

Source: Author's calculations from STATA, 2018.

net interest margin and bank performance unlike with the FE model where it was insignificant with bank performance. With the capital adequacy ratio, the study observed a negative relationship with bank performance though, in both models, the capital adequacy ratio had no impact on bank performance.

After that, a Hausman specification test was performed to identify the most suitable model from the two models employed namely the fixed effects model and the random effects model.

$\mathrm{b}=$ consistent under $\mathrm{Ho}$ and $\mathrm{Ha}$; obtained from xtreg; where $\mathrm{Ho}=\mathrm{Null}$ hypothesis and $\mathrm{Ha}=$ Alternative hypothesis.
$\mathrm{B}=$ inconsistent under $\mathrm{Ha}$, efficient under Ho; obtained from xtreg.

Test: Ho: difference in coefficients not systematic. Prob>chi2 = 0.0022,Ha: $\mathrm{p}$-value decision considered.

In Tab. VII, Hausman specification test suggests that fixed effects model was better than random effects model as its p-value is 0.0022 which is less than 0.05 for ROAA as the dependent variable and this means that random effects model should be rejected, and hence the analysis is conducted by employing fixed effects estimator. Therefore, given the above results of the Hausman specification test in vii, the study confidently accepts fixed effects model as the best model for the current research work.

\section{CONCLUSIONS}

The main aim of this study was to investigate the impact of bank-specific (internal) factors of profitability to the Hungarian commercial banks for the period ranging from 2000-2015.

The study used balanced panel data of a sample of twenty-six commercial banks with four hundred sixteen observations from 2000-2015. The study used return on average assets (ROAA) as the performance indicator with bank-specific variables that included non-performing loans, overhead costs, bank size, net interest margin, and liquidity risk as well as capital adequacy ratio. From the empirical findings, the study showed that the bank-specific variables profoundly influence the profitability of commercial banks in Hungary. This meant that bank profitability for Hungarian commercial banks is dependent upon the bank-level management variables for the period under investigation. These findings are very crucial for proposing optimal policies to bank management on how they can enhance profitability. Profitability is associated with banks that hold an optimal amount of liquid assets, lower levels of non-performing loans combined with efficient overhead costs management. The study findings reveal that the profitability of commercial banks in Hungary can be improved by enhancing the quality of assets (NPL), improving overhead costs management and liquidity.

The study concludes that bank size and asset quality are bank-specific (internal) factors that have the most significant impact on commercial banks' performance in Hungary for the period under investigation. Meanwhile, non-performing loans, overhead costs and liquidity had a negative effect on the financial performance of commercial banks. This meant that any increase in non-performing loans, overhead costs and increased liquid assets reduces profitability. Bank size had a positive impact on profitability. This just meant that an increase in the level of bank size would increase the profitability of commercial banks.

However, net interest margin and capital adequacy ratio had a positive and insignificant effect on bank profitability. This just meant that those two variables in question had no impact on bank performance. Thus as a matter of recommendation, the study findings show that they are relevant to policymaking in the sense that commercial banks should endeavour to manage and reduce overhead costs to be able to earn more profits since overhead costs adversely affect profitability. In the same vein, commercial banks should work on enhancing the asset quality together with the liquidity to improve the profitability position. As for commercial banks' managers, the study suggests that they should regularly monitor the credit and liquidity risk indicators as well as pursuing diversification policies of income sources while upholding optimisation of operational costs. 
Acknowledgements

"This research was funded by Internal IGA project no.PEF_TP_2018006 at Mendel University, Faculty of Business and Economics"

\section{REFERENCES}

ABEL, S. and LEROUX, P. 2016.Determinants of banking profitability in Zimbabwe, International Journal of Economics and Financial Issues, 6(3): 845-854.

ACARAVCI, S. K. and CALIM, A. E. 2013.Turkish banking sector's profitability factors, International Journal of Economics and Financial Issues, 3(1): 27-41.

ACHOU, F. T. and TEGNUH, N. C. 2008. Bank performance and credit risk management, master degree project, school of technology and society. University of Skovde press.

AKBAS, H. E. 2012. Determinants of bank profitability, an investigation on Turkish banking sector, In Oneri Dergisi, 10(37):103-110.

ALEXIOU, C. and SOFOKLIS, V. 2009. Determinants of bank profitability, evidence from the Greek banking sector, In Economski anali, 54(182): 93-118.

ALKHATIB, A. and HARSHEH, M. 2012. Financial performance of Palestine commercial banks, International Journal of Business and Social Science, 3: 175-184.

ALSHATTI, A. S. 2015.The effect of credit risk management on the financial performance of the Jordanian commercial banks, Investment Management and Financial Innovations, 12(1): 338-345.

ATHANASOGLOU, P. P., BRISSIMIS, S. N. and DELIS, M. D. 2005. Bank-specific, Industry-specific and macroeconomic determinants of bank profitability. Working paper, 25. Bank of Greece.

ATHANASOGLOU, P. P., DELIS, M. D. and STAIKOURAS, C. K. 2006. Determinants of bank profitability in the southeastern European region. Working paper, 25. Bank of Greece.

AYANDA, A. M., CHRISTOPHER, E. I. and MUDASHIRU, M. A. 2013. Determinants of banks' profitability in a developing economy, evidence from the Nigerian banking industry, Interdisciplinary Journal of Contemporary Research in Business, 4: 155-181.

BARAJAS, A., STEINER, R. and SALAZAR, N. 1999. Interest spreads in banking in Colombia, 1974-76. IMF staff papers, 46: 196-224.

BERGER, A. N. 1995.The profit-structure relationship in banking-Tests of market power and efficient - structure hypotheses. Journal of Money, Credit and Banking, 27(2):404-431.

BHATIA, A., MAHAJAN, P. and CHANDER, S. 2012. Determinants of profitability of private sector banks in India. Indian Journal of Accounting, 42(2):39-51.

BIKKER, J. A. and HU, H. 2002. Cyclical patterns in profits, provisioning and lending of banks and procyclicality of the new Basel capital requirements. BNL, quarterly review, 221:143-175.

DERMIGUC-KUNT, A. and HUIZINGA, H. 1999. Determinants of commercial bank interest margins and profitability: Some international evidence. The World Bank Economic Review, 13:379-408.

ELSIEFY, E. 2013. Comparative analysis of Qatari Islamic banks' performance versus conventional banks before, during and after the financial crisis, International Journal of Business and Commerce, 3(3): 11-41.

EPURE, M. and LAFUENTE, I. 2012. Monitoring performance in the presence of risk. Working Paper no. 613. Barcelona GSE working paper series.

FELIX, A. T. and CLAUDINE, T. N. 2008. Bank performance and credit risk management. Unpublished master's dissertation in Finance, Skovde, and University of Skovde.

FISCHER, S. and SAHAY, R. 2000. The transition economies after ten years. IMF working paper, (00/30). IMF.

GODDARD, J. A., MOLYNEUX, P. M. and WILSON, J. O. S. 2004.Dynamics of growth and profitability banking, Journal of Money Credit and Banking, 36(6): 1069-1090.

GOLIN, J. 2001. The bank credit analysis handbook: A guide for analysts, bankers and investors. John Wiley and sons, Asia.

GUJARATI, D. N. 2003. Basic Econometrics. $4^{\text {th }}$ Edition. New York: McGraw-Hill.

HANDLEY-SCHACHLER, M., JULEFF, L. and PATON, C. 2007. Corporate governance in the financial services sector, Corporate Governance, 7: 623-634.

HASSAN, M. K. and BASHIR. A. 2003.Determinants of Islamic banking profitability. In: Economic Research Forum. $10^{\text {th }}$ Annual conference, Marrakesh-Morocco.

KALLUCI, I. 2011. Analysis of the Albanian banking system in a risk performance framework. In: Proceeding of $3^{\text {rd }}$ annual south-eastern economic research workshop. Bank of Greece and bank of Albania.

KARGI, H. S. 2011. Credit risk and performance of Nigerian banks. Department of accounting, faculty of administration, Ahmadu Bello University, Zaria.

KODITHUWAKKU, S. 2015. Impact of credit risk management on the performance of commercial banks in Sri Lanka". International Journal of Scientific Research and Innovative Technology, 2(7):1-6.

KOSMIDOU, K., TANNA, S. and PASIOURAS, F. 2005. Determinants of profitability of domestic UK commercial banks: panel evidence from the period 1995-2002. In: Money Macro and Finance (MMF) Research Group and Conference 2005, 45. Money Macro and Finance Research Group. 
KUMBIRAI, M. and WEBB, R. 2010. A financial analysis ratio of commercial bank performance in South Africa, African Review of Economics and Finance, 2: 30-53.

LEE, C. C. and HSIEH, M. F. 2013. Beyond bank competition and profitability: Can moral hazard tell us more? Journal of Financial Services Research, 44(1):87-109.

LI, F. and ZOU, Y. 2014. The impact of credit risk management on the performance of commercial banks, a study of Europe. Umea school of business and economics.

LIPUNGA, A. M. 2014. Determinants of profitability of listed commercial banks in developing countries: evidence from Malawi. Research Journal of Finance and Accounting, 5(6): 41-49.

LIU, H. and WILSON, J. O. S. 2010. The profitability of banks in Japan. Applied Financial Economics, 20: 1851-1856.

MAKKAR, A. and SINGH, S. 2013. Analysis of the financial performance of Indian commercial banks, A comparative study. Indian Journal of Finance, 7: 41-49.

MANSUR, I., ZANGENEH, H. and ZITZ, M. S. 1993. The association between banks' performance ratios and a market-determined measure of risk. Journal of Applied Economics, 25: 1503-1510.

MARSHAL, J. 2009. The financial crisis in the US: key events, causes and responses. House of Commons library research paper, 09/34. House of Commons Library.

JARA-BERTIN, M.,ARIAS, MOYA,J. and RODRIGUEZPERALES,A. 2014. Determinants of Bank Performance: evidence from Latin America. Academia Revista Latino Americana de Administracion, 27(2): 164-182.

MENICUCCI, E. and PAOLUCCI, G. 2016. The determinants of bank profitability: Empirical evidence from the European banking sector, Journal of Financial Reporting and Accounting, 14(1):86-115.

NACEUR, S. B. and GOAIED, M. 2001.The determinants of the Tunisian deposit banks' performance. Applied Financial Economics, 11: 317-319.

NSHIYIMANA, Y. C. and ZUBEBA, M. A. 2017.The influence of economic factors on the profitability of commercial banks. International Journal of management and applied sciences, 3(1): 14-18.

OLALEKAN, A. and ADEYINKA, S. 2013. Capital adequacy and banks' profitability, empirical evidence from Nigeria, American International Journal of Contemporary Research, 3(10): 87-93.

ONGOLE, V. O. and KUSA, G. B. 2013. Determinants of the financial performance of commercial banks in Kenya, International Journal of Economics and Financial Issues,3: 237-252.

PODDER, B. 2012. Determinants of profitability of private commercial banks in Bangladesh: An empirical study. Thesis for a professional master in banking and finance, Asian Institute of technology in finance, Thailand.

SAEED, M. S. 2014. Bank-related, industry-related and macroeconomic factors affecting bank profitability: A case of the United Kingdom, Research Journal of Finance and Accounting, 5(2): 42-50.

SHOAIB, N., WANG, S., JALEEL, A. and PENG, K. 2015. Determinants of bank's profitability in Pakistan: A latest panel data evidence. International Journal of Economics, Commerce and Management, 3(4).

SIDDIQU, M.A.I. and SHOAIB, A. 2011. Measuring performance through the capital structure, Evidence from banking sector of Pakistan. African Journal of business management, 5: 1871-1879.

SUFIAN, F. and NOOR, M. A. N. N. 2012. Determinants of bank performance in a developing economy, does a bank origin matter? Global Business Review, 13(1): 1-23.

SUFIAN, F. and CHONG, R. R. 2008. Determinants of bank profitability in a developing economy, empirical evidence from the Philippines, Asian Academy of Management. Journal of Accounting and finance,4: 91-112.

TOBIAS, O. and THEMBA, M. S. 2011. Effects of sectoral banking factors on the profitability of commercial banks in Kenya. Economics and Finance Review, 1(5): 1-30.

WAHDAN, M. and LEITHY, W. 2017. Factors affecting the profitability of commercial banks in Egypt over the last five years(2011-2015). International Business Management,11(2): 342-349.

WEDER, B. 2001. Institutional reforms in transitional economies. IMF working paper (01/114). IMF. 